\title{
Technical Note: Anthropogenic and natural offline emissions and the online EMissions and dry DEPosition submodel EMDEP of the Modular Earth Submodel system (MESSy)
}

\author{
L. N. Ganzeveld ${ }^{1}$, J. A. van Aardenne ${ }^{2}$, T. M. Butler ${ }^{1}$, M. G. Lawrence ${ }^{1}$, \\ S. M. Metzger ${ }^{1}$, P. Stier ${ }^{3}$, P. Zimmermann ${ }^{1}$, and J. Lelieveld ${ }^{1}$ \\ ${ }^{1}$ Max-Planck Institute for Chemistry, Department of Atmospheric Chemistry, \\ Joachim-Becher-Weg 27, 55128, Mainz, P.O. Box 3060, 55020 Mainz, Germany \\ ${ }^{2}$ Joint Research Centre, Institute for Environment and Sustainability, Climate Change Unit, \\ Ispra (Va), Italy \\ ${ }^{3}$ California Institute of Technology, Pasadena, CA, USA
}

Received: 19 April 2006 - Accepted: 18 May 2006 - Published: 27 June 2006

Correspondence to: L. N. Ganzeveld (ganzevl@mpch-mainz.mpg.de)

\begin{abstract}
We present the online calculated Earth's surface trace gas and aerosol emissions and dry deposition in the Modular Earth Submodel System (MESSy) submodel EMDEP as well as the currently applied anthropogenic and natural emissions inventories. These 5 inventories, being read-in by the MESSy submodel OFFLEM, include the industrial, fossil fuel, agricultural and biomass burning emissions considering emission height profiles as a function of the source category based on the EDGAR v3.2 fast track 2000 inventory. Terrestrial and marine emissions of a selection of trace gases and aerosols are calculated online in EMDEP using climate model parameters such as wind speed,

10 temperature and land cover and land use parameters. The online dry deposition calculation includes gases and aerosols, where the default selection for the trace gases for the dry deposition scheme can be easily extended using a commonly applied method based on trace gas solubility and reactivity. In general, the simulated global annual emissions agree with previously reported inventories, although differences exist, partly

15 dependent on the applied model resolution. A high sensitivity of the simulated dry deposition to the applied emission height profiles stresses the importance of a realistic and consistent representation of the spatial and temporal variability in surface exchange processes in Earth system models.
\end{abstract}

\section{Introduction}

20 A key aspect of comprehensive models to study atmospheric chemistry and its role in the Earth system is the treatment of the surface boundary conditions, i.e., anthropogenic and natural emissions and dry deposition. The representation of these emissions and dry deposition is not only important for simulating realistic global burdens but also for the model evaluation in comparison to near-surface observations, which largely reflect the role of the temporal and spatial variability in surface exchanges and local photochemistry. Consequently the model representation of surface exchange 
processes should realistically incorporate some of the major drivers that determine this variability such as land cover and meteorological, biogeochemical and hydrological parameters. Here we provide a description of state-of-the-art representations of anthropogenic and natural emissions and dry deposition of reactive trace gases and

5 aerosols in the Modular Earth Submodel System (MESSy, see Jöckel et al., 2005) submodel EMDEP. This includes an anthropogenic and natural offline emission inventory (hereafter referred to as offline emission inventory), distributed with the first official release of MESSy (version 1.1), and the online calculated emissions and dry deposition surface fluxes with MESSy's submodel EMDEP. The later is the extensive development

10 and testing model for the representation of online emissions, dry deposition and canopy interactions (coupled representation of in-canopy dry deposition, biogenic emissions, turbulence and chemistry) (Ganzeveld et al., 2002) in MESSy.

The dry deposition and online emission routines of EMDEP actually provided the basis for the development of a distribution submodel for online emissions (ONLEM,

15 Kerkweg et al., 2006a) and one for dry deposition (DRYDEP, Kerkweg et al., 2006 $\mathrm{b}^{1}$ ). The processing of the tracer emission fluxes of the offline emission inventory to update the atmospheric tracer concentrations is being done with MESSy's submodel OFFLEM (Kerkweg et al., 2006a).

More details about the emissions included in the offline emission inventory are presented in Sect. 2 followed by a description in Sect. 3 of some of the fundamental concepts of online calculated emissions and dry deposition. In Sect. 4 we present the online emission budgets simulated with EMDEP with the major drivers of these emissions, e.g., surface temperature, wind speed, precipitation, being provided by the climate model ECHAM5 (Roeckner et al., 2003). To indicate the sensitivity of the online emissions to differences in the simulation of major drivers as a function of ap-

\footnotetext{
${ }^{1}$ Kerkweg, A., Buchholz, J., Ganzeveld, L., Pozzer, A., Tost, H., and Jöckel, P.: Technical Note: An implementation of the dry removal processes DRY DEPosition and SEDImentation in the Modular Earth Submodel System (MESSy), Atmos. Chem. Phys. Discuss., submitted, 2006b.
}

$$
5459
$$

plied GCM's model resolution, we present the calculated budgets for three resolutions. Moreover, we present some first analysis of the sensitivity of dry deposition calculations to the inclusion of emissions heights in the offline emission inventory, followed by a summary and conclusions.

\section{Offline emission inventory}

The representation of surface emissions in EMDEP includes a selection of terrestrial and marine natural emissions which are calculated online whereas technologically driven emissions and a selection of natural emissions, some with an anthropogenic component such as biomass burning, are included in preprocessed input files, referred 10 to as offline emissions, and read in for use in MESSy using the submodel OFFLEM.

These offline sources include a large selection of technological-, agricultural, biomass burning- and terrestrial biogenic and oceanic emissions of mostly trace gases. For the technological, agricultural and biomass burning emissions we use the EDGAR (Emission Database for Global Atmospheric Research, http://www.mnp.nl/edgar/)

15 v3.2 fast-track update of the emissions for the year 2000 (hereafter referred to as EDGARv3.2-FT2000). For more details we refer to Olivier et al. (2005), Van Aardenne et al. (2005) and Van der Werf et al. (2003), discussing here some specific features relevant to the compiled inventory.

The EDGARv3.2-FT2000 dataset differs from the EDGARv3.2 dataset representing the 1995 emissions such that it is based on the activity data for the year 2000 applying the same emission factors as in EDGARv3.2 except for countries for which new information about emission control measures has become available. A new feature of the offline emissions is that emission height profiles have been assigned to the different EDGAR source categories distinguishing six effective emission heights $25(45,140,240,400,600$ and $800 \mathrm{~m}$ a.g.I.) based on profiles used in the EMEP (Cooperative Programme on the Long-Range Transmission of Air Pollutants in Europe, http://www.emep.int) model. For those categories not mentioned in the EMEP work, 
we arbitrarily assumed that the effective emission height is less than $45 \mathrm{~m}$, except of ship emissions for which we assume that a substantial fraction is emitted at a higher altitude of $145 \mathrm{~m}$.

The emission profiles are shown in Table 1. The sensitivity of simulated atmospheric 5 chemistry to biomass burning emission height profiles, as recommended by van Aardenne et al. (2005), considering a larger vertical extent of emission heights compared to the domain described above, is currently being tested and will be included in a future release of the offline emission inventory.

The EDGARv3.2-FT2000 provides only emissions of total non-methane volatile or-

10 ganic compounds (NMVOC). To obtain the emissions of each individual NMVOC represented in the offline emission inventory, this total mass of NMVOC is first converted to a mass of carbon using the ratios from Table 4.7(b) of the IPCC Third Assessment Report. This total mass of carbon is then partitioned between the NMVOC species using the speciation ratios from von Kuhlmann et al. (2003) which in turn are for an-

15 thropogenic emissions based on the EDGAR v2.0 inventory and for biomass burning and biofuel emissions based on Andrea and Merlet (2001) for biomass burning and biofuel emissions.

The terrestrial biogenic and oceanic emissions of NMVOC's are similar to the emissions in the inventory applied in the offline chemistry and tracer transport model

20 MATCH-MPIC (Von Kuhlmann et al., 2003; Lawrence et al., 1999, hereafter MATCH). Although the biogenic emissions of terpenes and other reactive volatile organic compounds (ORVOC's) are calculated online (see Sect. 3.1), which could be used to provide the first-order estimate of biogenic $\mathrm{CO}$ and acetone emissions, we use the Guenther et al. (1995) global annual estimates of terpene and ORVOC emissions to arrive at the biogenic emission budgets of $\mathrm{CO}$, acetone, methanol, alkanes, alkenes, aldehydes and acids. Oceanic emissions of $\mathrm{CO}$ and NMVOC's are also included. In addition, we apply the Bouwman (1997) dataset for ammonia $\left(\mathrm{NH}_{3}\right)$ emissions, made available through the Global Emission Inventory Activity (GEIA, Guenther et al., 1995).

To indicate the source strength of the anthropogenic and natural offline emissions

5461

we present in Table 2 the global annual technological, biofuel, biomass burning and total emissions (with the biogenic component). Note that biomass burning emissions refer to the year 2000, based on average activity data over the period 1997-2001. For specific years within this period the actual biomass burning estimates are now available 5 as well but have not yet been applied here. Also shown are the budgets of a selection of offline terrestrial and oceanic biogenic emissions, including CO and NMVOC's, based on the MATCH model emission dataset, about which more details can be found in von Kuhlmann et al. (2003). The MATCH emission budgets are based on the 1990 EDGARv2 inventory for technological emissions and the biomass burning inventory by

10 Galanter et al. (2000). Consequently, the comparison of global emission budgets indicates about the differences between the EDGARv2 and v3.2-F2000 as well as the biomass burning emissions. The largest differences occur in the $\mathrm{NO}_{\mathrm{x}}, \mathrm{CO}$ and $\mathrm{C}_{4} \mathrm{H}_{10}$ global emissions, with changes (relative to the MATCH inventory) of $+33,-13$ and $+54 \%$. The significantly larger total $\mathrm{NO}_{\mathrm{x}}$ source is mostly due to larger ship emis15 sions in EDGARv3.2-FT2000 (Eyring et al, 2005) compared to EDGARv2 and larger biomass burning emissions, both about $4 \mathrm{TgN} \mathrm{yr}^{-1}$ larger compared to the MATCH inventory. These differences do not only reflect differences in inventory compilation but obviously also differences between 1990 and 2000. The smaller CO emissions in the presented inventory compared to the MATCH inventory are mostly due to an about

$2050 \mathrm{TgC} \mathrm{yr}^{-1}$ smaller technological emission flux of the EDGARv3.2-FT2000 inventory compared to EDGARv2 whereas EDGARv3.2-FT2000 includes an about $20 \mathrm{TgC} \mathrm{yr}^{-1}$ larger $\mathrm{C}_{4} \mathrm{H}_{10}$ emission flux compared to EDGARv2. The latter difference is explained by

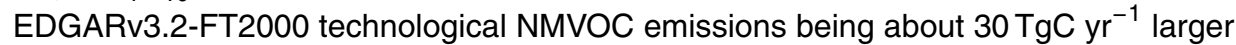
compared to EDGARv2 for an NMVOC speciation such that $\mathrm{C}_{4} \mathrm{H}_{10}$ makes up $70 \%$ of

25 the technological NMVOC emissions. The biogenic $\mathrm{NH}_{3}$ emission reflects the agricultural $\mathrm{NH}_{3}$ inventory by Bouwman et al. (1997). 


\subsection{Online emissions}

For more details concerning the description of the emissions mostly relevant to aerosol modeling, including the emissions of marine DiMethylSulfide (DMS) and sea salt, ter-

5 restrial DMS, volcanic $\mathrm{SO}_{2}$, mineral dust, and fossil fuel and biomass burning organic and black carbon, we refer to Dentener et al. (2006) and Stier et al. (2005). The implementation of a selection of algorithms to calculate the natural emissions of DMS, sea salt and mineral dust allows that the model can be used at different resolutions to study the sensitivity for a range of global flux estimates as well as controlling parameters such

10 as the surface layer wind speed. The DMS emissions, which are calculated from the $10 \mathrm{~m}$ wind speed and a climatology of the ocean water DMS concentrations according to Kettle and Andreae (2000), can be calculated by selecting one of different available parameterizations of the piston velocity according to Liss and Merlivat (1986), Wanninkhof (1992) or Nightingale (2000). Similarly, sea salt emissions can be simulated

15 using algorithms based on Monahan (1986) or Schulz et al. (2004). Mineral dust emissions are simulated according to Balkanski et al. (2004) where alternative algorithms, e.g. based on Tegen et al. (2002), will become available in future updated model versions (see also Sect. 4). Other online calculated natural sources involve soil-biogenic $\mathrm{NO}_{x}$ and vegetation emissions of NMVOC's. Soil-biogenic $\mathrm{NO}_{x}$ emissions are calcu-

20 lated according to a modified version of the Yienger and Levy (1995) algorithm initially implemented and applied in the chemistry-climate model ECHAM4 to study the role of canopy processes for global soil-biogenic $\mathrm{NO}_{\mathrm{x}}$ emissions (Ganzeveld et al., 2002). To actually consider the role of deposition, chemical transformations and turbulence within the canopy, a Canopy Reduction Factor (CRF) (Yienger and Levy (1995) is used as a 25 default since the study by Ganzeveld et al. (2002) indicated that the ecosystem specific CRF provides reasonable estimates of the atmosphere-biosphere $\mathrm{NO}_{x}$ flux compared to an explicit multi-layer canopy model. One further modification relevant to mention is that in the version implemented in EMDEP not only the contribution to soil NO emis5463

sions by synthetic fertilizer application but also that due to animal manure is considered (A. F. Bouwman, personal communication, 2004). However, despite a near doubling of the $\mathrm{N}$ input, there is actually a decrease in the global annual $\mathrm{NO}$ emissions related to agricultural activities due to the fact that the fractional loss of the amount of fertilizer, 5 which was previously set at $2.5 \%$ (Yienger and Levy, 1995), has been reduced to $0.7 \%$ (Bouwman et al., 2002).

Biogenic NMVOC emissions are calculated according to the Guenther et al. (1995) algorithm based on the global distribution of the 72 ecosystems of the Olson (1992) database. The latter, in combination with a Normalized Difference Vegetation Index

10 (NDVI) satellite dataset, provides monthly estimates of the biomass (foliar density and Leaf Area Index, LAI), which are applied not only to calculate the emissions of isoprene, monoterpenes and other VOC's, but also dry deposition and soil-biogenic $\mathrm{NO}_{\mathrm{x}}$ emissions.

Finally, in EMDEP there is the option to consider the emissions of methane $\left(\mathrm{CH}_{4}\right)$, 15 which are, in the current implementation, not calculated online but inferred from the difference in the simulated surface layer and observed surface layer $\mathrm{CH}_{4}$ concentrations. The latter are based on observations from the NOAA/CMDL cooperative air sampling network (Dlugokencky, 1994) processed using the methodology of Butler (2004).

\subsection{Gaseous and aerosol dry deposition}

20 A major limitation to introduce improved representations of the dry deposition process in large-scale models such ECHAM5/MESSy is the fact that dry deposition has only been directly measured for a small selection of gases and aerosols such as ozone $\left(\mathrm{O}_{3}\right)$, sulfur dioxide $\left(\mathrm{SO}_{2}\right)$ ammonia $\left(\mathrm{NH}_{3}\right)$ and sulfate $\left(\mathrm{SO}_{4}^{2-}\right)$. Merely a limited number of dry deposition measurements of other species such as peroxides (hydrogen perox-

25 ide, $\left.\mathrm{H}_{2} \mathrm{O}_{2}\right)$, nitric acid $\left(\mathrm{HNO}_{3}\right)$ and other oxidized nitrogen species such as nitrogen (di)oxide $\left(\mathrm{NO}_{2}\right.$ and $\mathrm{NO}$ ) have been performed, whereas measurements are also generally biased towards vegetation dry deposition. Observations of dry deposition over the oceans, snow-ice covered and bare soil surfaces are sparse, which not only limits a 
better quantification of the role of dry deposition in tracer budgets over these surfaces, but also the identification of controlling mechanisms required for the further advancement of model representations. The understanding of the mechanisms is mostly limited to that of turbulent transport and diffusion to the surface and some surface related 5 mechanisms such as the stomatal uptake of gases such as $\mathrm{O}_{3}$ and $\mathrm{SO}_{2}$. For a comprehensive overview of the status of dry deposition research we refer to Wesely and Hicks (2000).

To at least provide first-order estimates of the potential role of dry deposition of gases for which no direct dry deposition measurements are available Wesely (1989)

10 introduced a commonly applied approach by which surface uptake resistances are estimated based on solubility and reactivity by scaling to those of $\mathrm{O}_{3}$ and $\mathrm{SO}_{2}$. A nonsoluble but reactive gas is expected to deposit like $\mathrm{O}_{3}$ whereas a more soluble and less reactive gas should deposit like $\mathrm{SO}_{2}$. The default selection of gases included in the dry deposition scheme of EMDEP (and DRYDEP) are $\mathrm{O}_{3}, \mathrm{SO}_{2}, \mathrm{HNO}_{3}, \mathrm{NO}$ and $\mathrm{NO}_{2}$, com-

15 plemented with bulk sulfate aerosol dry deposition (Ganzeveld and Lelieveld, 1995; Ganzeveld et al., 1998) for studies that include sulfur chemistry but do not explicitly resolve aerosol mass size distributions (see below).

Dry deposition fluxes are calculated as the product of the surface layer concentration and the dry deposition velocity, which reflects the efficiency of the transport to- and de20 struction at the surface. The dry deposition velocity $\left(\mathrm{V}_{d}\right)$ is calculated according to the so-called "big leaf" approach where the vegetation canopy, or other surface, is represented as a bulk substrate without considering in detail the different removal processes at different levels in the canopy. In analogy to the resistance against electrical conductivity, $V_{d}$ is calculated as the reciprocal of three serial resistances that represent the urbulent transport to the surface, molecular diffusion through a quasi-laminar boundary layer and finally uptake and destruction by the surface. The turbulent transport or so-called aerodynamic resistance $\left(R_{a}\right)$ is calculated from the wind speed, surface roughness and atmospheric stability whereas the quasi-laminar boundary layer resistance $\left(R_{b}\right)$ is calculated from the same parameters and the trace gas specific molec-

\section{5}

ular diffusivity. The vegetation surface uptake resistance $\left(R_{c}\right)$ is calculated from the leaf/needle resistance, scaled up to the canopy scale by using the Leaf Area Index (LAI, single-sided leaf area per soil area), a species-specific soil uptake resistance and a resistance that accounts for turbulent transport through the canopy to the soil. The

5 leaf resistance in EMDEP is calculated from the stomatal uptake resistance, generally being provided by the driver model (e.g., in ECHAM5 to calculate evapotranspiration according to Sellers, 1986), corrected for differences in diffusivity between $\mathrm{H}_{2} \mathrm{O}$ and the gas, and species-specific mesophyllic and cuticular uptake resistances. For details concerning the selected values for the default selection of gases of the dry deposition 10 scheme, we refer to Ganzeveld and Lelieveld (1995) and Ganzeveld et al. (1998). For any other trace gas to be added to the dry deposition scheme, e.g., oxygenated compounds or acids, the only modification to be made is to define the tracer specific Henry Law's coefficient $\left[\mathrm{m} \mathrm{atm}{ }^{-1}\right]$, a reactivity coefficient $[0,0.1,1]$ (with 0 for species that are poorly reactive on surfaces, e.g. acetaldehyde, 0.1 for semi-reactive species, e.g., 15 peroxyacetylnitrate and 1 for highly reactive species, e.g., $\mathrm{O}_{3}$ ) and its molar mass (see Appendix A).

A main new feature of the dry deposition calculations in EMDEP is the online calculation of aerosol dry deposition as a function of aerosol properties, meteorology and surface cover. Aerosol dry deposition velocities $\left(\mathrm{V}_{\text {daerosol }}\right)$ and fluxes are calculated with

20 a modified version of the aerosol dry deposition model that has been used to develop a parameterization of the bulk sulfate aerosol dry deposition in the chemistry-climate model ECHAM4 (Ganzeveld et al., 1998). The online aerosol dry deposition code has also been implemented and applied in the aerosol-climate model ECHAM5-HAM (Stier et al., 2005).

25 The model calculates $\mathrm{V}_{\text {daerosol }}$ over land and over sea considering turbulence, Brownian diffusion, impaction and sedimentation as a function of radius and density. Over sea the effect of particle growth on dry deposition due to the large relative humidity close to the sea surface is accounted for as well as bubble bursting that enhances dry deposition through the breakdown of the laminar boundary layer and the scaveng- 
ing of the particles by sea spray (Hummelshøj, 1992). The main modification in the aerosol dry deposition model is the calculation of the vegetation dry deposition velocities, whereas in the Ganzeveld et al. (1998) model we applied a parameterization of sulfate aerosol dry deposition as a function of the friction velocity for stable and un-

5 stable conditions developed by Wesely et al. (1985). In the new model aerosol dry deposition to the vegetation is calculated according to Gallagher et al. (2002), which is a further modification of a parameterization of aerosol dry deposition by Slinn (1982). In contrast to Zhang et al. (2001) we have selected a smallest and a largest collector size of $10 \mu \mathrm{m}$ and $1 \mathrm{~mm}$, respectively, independent of land cover, partly associated with

10 the large uncertainty involved in the definition of these parameters. The largest collector size is used to calculate the Stokes number, which is not only used to calculate impaction but also a rebound correction factor, whereas the small collector size is used to calculate the interception collection efficiency (Gallagher et al., 2002). More details concerning the use of the aerosol dry deposition model are found in the Appendix A.

\section{Global emission budgets and dry deposition}

Table 3 shows the global annual emissions for a selection of reactive trace gases and aerosols simulated with EMDEP, applied in ECHAM5/MESSy (version 1.1), for an 1year climatological model integration (1 month spin-up, reference year 1987-1988) with the T42L19 (i.e., $2.8^{\circ}$ grid resolution, 19 vertical levels) resolution of ECHAM5. The global isoprene $\left(\mathrm{C}_{5} \mathrm{H}_{8}\right)$ emission flux of $607 \mathrm{TgC} \mathrm{yr}^{-1}$ is significantly larger compared to the estimate by Guenther et al. (1995) and the online simulated source of $500 \mathrm{TgC} \mathrm{yr}^{-1}$ with the chemistry-climate model ECHAM4 (Ganzeveld et al., 2002). The latter was calculated at a T31L19 spatial resolution with significantly larger estimates of vegetation biomass compared to that used in the current implementation of biogenic emission

25 and dry deposition calculations in EMDEP. In ECHAM4 the maximum Leaf Area Index (LAI) for tropical forest even exceeded $10 \mathrm{~m}^{2} \mathrm{~m}^{-2}$ whereas observations show maximum values up to about 6-7. Consequently we apply a function that provides an 5467

asymptotic increase in LAI to a maximum of 7 for the maximum observed Normalized Differential Vegetation Index (NDVI) (Ganzeveld et al., 2002). In addition, we have consistently corrected the foliar density (leaf biomass in $\mathrm{g} \mathrm{m}^{-2}$ ) which is used to calculate the biogenic VOC emissions. Interestingly, a relative increase in the simulated frac-

5 tion of sunlit leaves partly compensates this decrease in foliar density. The budgets of the monoterpene $\left(\mathrm{C}_{10} \mathrm{H}_{16}\right)$ and ORVOC's emissions of 143 and $255 \mathrm{TgC} \mathrm{yr}^{-1}$, that are calculated by EMDEP using ECHAM5's surface temperature, agree reasonable well with the estimates by Guenther et al. (1995) of 127 and $260 \mathrm{TgC} \mathrm{yr}^{-1}$, respectively. This suggests that EMDEP's larger isoprene emission flux, compared to the Guenther 10 et al. (1995) inventory, is mostly due to differences between the EMDEP online simulated surface and in-canopy radiation regime, using ECHAM5's surface net radiation, compared to the offline approach by Guenther et al. (1995), and not so much due to differences in temperature. Note that the simulated isoprene emission budget is nearly a factor two larger compared global isoprene flux of $350 \mathrm{TgC} \mathrm{yr}^{-1}$ by von Kuhlmann et 15 al. (2003), which applied a global scaling factor to the online calculated emission fluxes and which is a common approach widely applied in global scale atmospheric chemistry model analysis. This is generally being justified by the fact that use of the $500 \mathrm{TgC} \mathrm{yr}^{-1}$ inventory results in simulated tropical boundary layer isoprene concentrations that are significantly larger compared to observations. This misrepresentation is likely also due

20 to the models representations of boundary layer mixing, dry deposition (of isoprene and the oxidation products) and chemical destruction (von Kuhlmann et al., 2004) and not only a possible overestimation of emissions. Interestingly, a new inventory of the global isoprene emissions with the MEGAN model (Guenther et al., 2006), which incorporates the newly acquired information on biological, physical and chemical drivers

25 since the release of the Guenther et al. (1995) inventory, provides a global isoprene

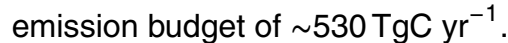

The LAI is also used in the calculation of the Canopy Reduction Factor (CRF), which provides estimates of the soil-biogenic $\mathrm{NO}_{\mathrm{x}}$ emissions comparable to those calculated with an explicit multi-layer canopy model implemented in ECHAM4 (Ganzeveld et al., 
2002). Table 3 shows that the online simulated global soil NO flux of $12.4 \mathrm{TgN} \mathrm{yr}^{-1}$ is reduced by about 35\% with maximum decreases in tropical forested regions up to about $75 \%$. Pulsing, which is the enhancement in emissions in response to rainfall after a period of drought, enhances the soil $\mathrm{NO}$ emission by about $2 \mathrm{TgN}_{\mathrm{yr}}{ }^{-1}$ whereas

5 fertilizer application and animal manure contribute about $0.7 \mathrm{TgN} \mathrm{yr}^{-1}$. The latter is about the half the contribution by fertilizers to global soil NO emissions inferred from a statistical modeling approach by Bouwman et al. (2002). This can be explained by the fact that the fertilizer application is corrected for a prescribed global distribution of cultivation intensity determining the timing of fertilizer application. Consequently, we 10 apply in EMDEP a fractional fertilizer loss of $1.5 \%$ to arrive at a contribution by fertilizers to global soil-biogenic $\mathrm{NO}_{\mathrm{x}}$ emissions of $1.5 \mathrm{TgN} \mathrm{yr}^{-1}$.

The global annual DMS emission flux, calculated in this simulation with the Liss and Merlivat (1986) parameterization for the piston velocity, is $17.3 \mathrm{TgS}^{-1}$. This is about $6 \mathrm{TgS}$ less compared to the number reported by Stier et al. (2005). This also reflects

15 the sensitivity to the parameterization applied for the piston velocity (Nightingale, 2000) that was used by Stier et al. (2005). Note that in addition to this major biogenic source of sulfur, terrestrial DMS and volcanic $\mathrm{SO}_{2}$ emissions, amounting to about $1 \mathrm{TgS} \mathrm{yr}^{-1}$

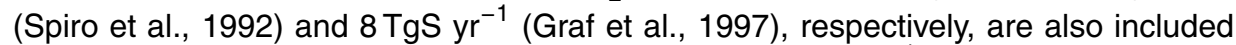
in EMDEP. The sea salt emission flux of $5906 \mathrm{Tg}$ sea salt $\mathrm{yr}^{-1}$, calculated according

20 to Schulz et al. (2004), is larger compared to the emissions budgets presented by Stier et al. (2005) (5050 $\mathrm{Tg} \mathrm{yr}^{-1}$ ). One possible explanation for this discrepancy are differences in the surface wind speed as the emissions were obtained with the T42L19 model resolution whereas Stier et al. (2005) applied an T63L31 (ECMWF) resolution. In addition, our emission budget reflects an ECHAM5 climatological simulation whereas

25 the results by Stier et al. (2005) reflect emissions for a simulation where ECHAM5 has been nudged towards the ECMWF ERA40 reanalysis data. The nudging results in a slightly smaller sea salt emission burden compared to climatological simulations due to a relative decrease in the wind speeds. This has an even more pronounced impact on the simulated mineral dust emissions, which partly explains an calculated

5469

global annual emission flux according to our implementation of the scheme according to Balkanski et al. (2004) with EMDEP of $1432 \mathrm{Tg} \mathrm{yr}^{-1}$, about $680 \mathrm{Tg}$ larger compared than that presented by Stier et al. (2005). This is consistent with other simulations of mineral dust emissions, calculated according to Tegen et al. (2002), which also showed 5 a significant decrease in the nudged model simulations compared to a climatological simulation with the same model resolution.

In Table 3 we not only present global emission burden for biogenic $\mathrm{NO}_{\mathrm{x}}$, VOC, DMS and sea-salt and mineral dust aerosol mass for the T42L19 model resolutions but also include the budgets for the T21L19 $\left(\sim 5.6^{\circ}\right)$ and T63L19 $\left(\sim 1.8^{\circ}\right)$ model resolution. Note

10 that for the T63 resolution, the 31 layer (L31) vertical structure is generally recommended, but here we have consistently applied the L19 vertical resolution. In general the emissions increase with an increase in resolution from T21 to T63 with relative increases (T63-T21 relative to T42 emissions) up to about $10 \%$ for isoprene and DMS and about $20 \%$ for monoterpenes, ORVOC and sea salt, whereas soil-biogenic $\mathrm{NO}_{\mathrm{x}}$ emissions actually show a small decrease. These changes reflect differences in the simulated net surface radiation, temperature, wind speed, precipitation and soil moisture for the different model resolutions.

The mineral dust emissions are extremely sensitive to the applied resolution suggesting that the implementation of the emission algorithm by Balkanski et al. (2004) in

20 EMDEP should only be applied for the T42 resolution since only for this resolution it produces emissions fluxes comparable to those reported by Tegen et al. (2002) in a climatological run with ECHAM5. For other resolutions, for example the T63 simulation we simulate a global emission strength $>8000 \mathrm{Tg} \mathrm{yr}^{-1}$ mostly due to very large emissions in Pakistan and north of the Himalaya contributing $>85 \%$ of the global emissions 25 also due to simulated monthly mean $10 \mathrm{~m}$ wind speeds exceeding $20 \mathrm{~m} \mathrm{~s}^{-1}$. Alternative algorithms to simulate mineral dust emissions, e.g., the one by Tegen et al. (2002), potentially being less sensitive to the applied resolution will be implemented in EMDEP in the near future. 


\subsection{Dry deposition and emission height profiles}

An important feature of the application of the emission inventory in OFFLEM is the consideration of emission height profiles for tracer transport calculations. To indicate the sensitivity of the simulated trace gas exchanges to the applied height profiles, we

5 present in Figs. $1 \mathrm{a}$ and $\mathrm{b}$ the relative difference in annual mean $\mathrm{SO}_{2}$ and $\mathrm{O}_{3}$ dry deposition fluxes between a simulation with ECHAM5/MESSy in which the precursors have been released at the surface and one applying the vertical redistribution of emissions up to $800 \mathrm{~m}$ altitude, as described above (Table 1). These results reflect a simulation with a setup similar to an that used for an evaluation of ECHAM5/MESSy (Jöckel et

10 al., 2006 $^{2}$ ) including tracer transport, gas-phase chemistry (Sander et al., 2005) and scavenging (Tost et al., 2006) except of a different vertical resolution (L19 versus L90), no nudging and using EMDEP instead of the submodels ONLEM and DRYDEP. The simulated $\mathrm{SO}_{2}$ dry deposition fluxes resulting from emitting all $\mathrm{SO}_{2}$ in the surface layer are up to $80 \%$ higher in the vicinity of the sources over the continents in low and middle

15 latitudes, whereas at larger distances from the sources e.g., over the eastern Sahara and Artic regions, large relative (but small absolute) decreases in dry deposition occur as a result of the decreased supply by long-range transport. Figure $1 \mathrm{~b}$ shows a relative smaller sensitivity of $\mathrm{O}_{3}$ deposition to the vertical emissions profiles of the precursor gases $\mathrm{CO}, \mathrm{NO}_{\mathrm{x}}$ and NMVOC's compared to $\mathrm{SO}_{2}$. There are relative decreases $>10 \%$

20 in $\mathrm{O}_{3}$ dry deposition in the main source regions with large technological and biomass burning emissions when those emissions are emitted away from the surface whereas the more effective long-range transport of the precursor gases explains the increases in the $\mathrm{O}_{3}$ deposition up to $15 \%$ in the northern hemisphere high latitude regions. The

\footnotetext{
${ }^{2}$ Jöckel, P., Tost, H., Pozzer, A., Brühl, Ch., Buchholz, J., Ganzeveld, L., Hoor, P., Kerkweg, A, Lawrence, M. G., Sander, R., Steil, B., Stiller, G., Tanarhte, M., Taraborrelli, D., van Aardenne, J., and Lelieveld, J.: The atmospheric chemistry general circulation model ECHAM5/MESSy1: Consistent simulation of ozone from the surface to the mesosphere, Atmos. Chem. Phys. Discuss., submitted, 2006.
}

5471

application of the emission height profiles results in a relative decrease in the global annual $\mathrm{SO}_{2}$ dry deposition flux up to about $30 \%$ compared to surface emissions simulations associated with a significant decrease in surface layer concentrations. This results in a significant increase in the $\mathrm{SO}_{2}$ lifetime and it enhances the long-range 5 transport of sulfur pollution. This sensitivity of dry deposition to the emission height is also relevant to the evaluation of ECHAM5/MESSy, addressed in our first extensive model evaluation publication (Jöckel et al., $2006^{2}$ ), which will also include a direct comparison of observed and simulated surface concentrations and dry deposition fluxes.

\section{Summary/conclusions}

${ }_{10}$ We have presented the state-of-the-art representation of surface reactive trace gas and aerosol exchanges describing an anthropogenic and natural offline emission inventory, distributed with the first official release of MESSy, and MESSy's submodel EMDEP. This includes a discussion of the mechanisms underlying the emissions and dry deposition calculations, global online calculated emission budgets with EMDEP

15 and an assessment of the sensitivity of dry deposition to the emission height profiles. This emission height is included in the offline emission inventory that includes the EDGARv3.2-FT2000 technological and biomass burning emission and prescribed terrestrial and oceanic emissions. The large sensitivity of the simulated dry deposition fluxes to the emission heights that are based on a limited amount of studies and

20 expert assumptions, and therefore accompanied with large uncertainty, indicates the priority of a better understanding and representation of the effective emission heights in models such as MESSy.

The online calculated gaseous and aerosol natural and biogenic emissions use the driver models micrometeorological and surface cover parameters complemented with

25 land cover and land use properties inferred from satellite data and global scale ecosystem and land use datasets.

Aerosol dry deposition is calculated considering turbulence, Brownian diffusion, im- 
paction, interception and sedimentation as a function of the models micrometeorology and land cover and aerosol radius. Gaseous dry deposition is calculated online for many species in addition to those for which dry deposition is known to be an important sink based on scarcely available measurement data. The scheme can be easily 5 extended to other species expected to be removed by dry deposition based on their chemical and physical properties, using the approach proposed by Wesely (1989). However, it should be noted that recent studies indicate that first-order estimates of the surface uptake resistances according to that approach seem to result in a significant underestimation of dry deposition of a selection of oxygenated species, measured

10 in the tropical forest of Costa Rica (Karl et al., 2004) and peroxides (Ganzeveld et al., 2006). This suggests that the approach needs modification which, however, is severely limited by the availability of observational data. Actually, the implementation of these first-order estimates of dry deposition in models such as EMDEP can help obtain indications about the potential relevance of the dry deposition process, and consequently 15 provide suggestions to the experimental community on the priority of further research focusing on dry deposition.

We have demonstrated the large impact of applying the EDGARv3.2-FT2000 recommended emission heights; for example, on the $\mathrm{SO}_{2}$ dry deposition flux. This is not only relevant to atmospheric chemistry with respect to a change in the lifetime and

20 atmospheric burden but also to the evaluation of models such as ECHAM5/MESSy. This evaluation relies on the comparison of observed and simulated concentrations and fluxes, including many surface observations, obviously being strongly affected by emission and deposition parameterisations. This underscores the need for improved and consistent representations of the spatial and temporal variability of surface exchange processes in Earth system models, including e.g. diel cycles in technological and biomass burning emissions.

\section{Appendix A}

The emission and dry deposition calculations in EMDEP are included in three different sub-submodels identified by the names EMDEP_XTSURF, EMDEP_DRYDEP and EMDEP_EMIS. The EMDEP_XTSURF routines deal with the initialization of land cover 5 and land use parameters, the tracer specific surface uptake resistances, and the actual calculations of the gaseous and aerosol "big leaf" dry deposition velocities from those surface resistances. These dry deposition velocities are then subsequently applied in EMDEP_DRYDEP to actually calculate the dry deposition fluxes, where alternative algorithms, e.g., based on prescribed deposition velocities, can also be included. In

10 EMDEP_EMIS the online emission are calculated from the driver model parameters and the land cover and land use parameters initialized in EMDEP_XTSURF. Note that the presented budgets reflect calculations with the EMDEP model, which is continuously further developed. Consequently differences in calculated emission and deposition budgets between EMDEP and ONLEM and DRYDEP are to be expected. Further

15 improvements in the online emission- and dry deposition calculations in EMDEP are intended to be implemented later into ONLEM and DRYDEP, respectively, as well, after they have been thoroughly tested. One of the future extensions of EMDEP will be the release of a version that includes a multi-layer canopy model to study the role of incanopy interactions between biogenic emissions, dry deposition, chemistry and turbu-

20 lent transport, previously used to study global soil-biogenic $\mathrm{NO}_{\mathrm{x}}$ exchanges (Ganzeveld et al., 2002).

\section{A1 Adding a tracer to the dry deposition calculations}

In order to include the explicit dry deposition calculations tracer specific properties need to set in the tracer definition. If the tracer is defined by the submodel MECCA (Sander

25 et al., 2005) in the file tracdef.tex, the dry deposition calculation switch NDRYDEP has to be set to ON. In addition, for gases the molecular mass, Henry law's coefficient $\left[\mathrm{mol} \mathrm{I}^{-1}\right]$ and a reactivity coefficient must be defined. The latter has only three values 
with 0 reflecting a non-reactive gas (e.g., acetone), 0.1 for an intermediate reactive gas (e.g., PAN), and 1 for a reactive gas (e.g., monoterpenes). Otherwise, these tracer properties must be set by definition of the respective tracer being considered in the various submodels. For aerosol dry deposition calculations information is required on the 5 aerosol density $\left[\mathrm{kg} \mathrm{m}^{-3}\right.$ ] and the aerosol number and mass radii [m]. The aerosol dry deposition code is programmed to simulate aerosol dry deposition for the implementation of a modal aerosol model conducting the calculations for the number of modes that are characterized by a median or mean mode radius, the sigma and wet aerosol density. However, the model can easily be modified for application in a bin-resolving

10 aerosol model or in a bulk aerosol model by simply defining representative bulk aerosol properties. By default the code calculates $\mathrm{V}_{\text {daerosol }}$ for or a more computational efficient method using the modal mean number and mass radii but the option exists to calculate $\mathrm{V}_{\text {daerosol }}$ integrating over the number- and mass size distributions.

\section{A2 Integration in vertical diffusion scheme}

15 The calculation of the concentration change due to surface exchanges can be done according to two different approaches which allow studying the possible impact of operator splitting involving surface exchanges and vertical turbulent diffusion. In the default set-up (set by the switch Iturb_emis in the EMDEP namelist) the calculated surface exchange fluxes [molecules $\mathrm{m}^{-2} \mathrm{~s}^{-1}$ ] are used as the lower boundary condition in the 20 vertical diffusion scheme of ECHAM5 (parameter ZXTEMS, [mol mol ${ }^{-1} \mathrm{~kg} \mathrm{~m}^{-2} \mathrm{~s}^{-1}$ ] for tracer defined in volume mixing ratio). The alternative is to assign fluxes to the tracer tendency (parameter PXTTE, [mol mol$\left.{ }^{-1} \mathrm{~s}^{-1}\right]$ ).

Acknowledgements. We highly appreciate the support by L. Bouwman for providing the animal manure data. In addition, the set-up of the emission datasets and algorithms used in EMDEP (and ONLEM) has greatly benefited from the help by the various colleagues who have developed the algorithms: S. Kloster (DMS emissions), I. Tegen and Y. Balkanski (mineral dust emissions), and M. Schulz (sea salt emissions).

\section{5}

\section{References}

Andreae, M. O. and Merlet, P.: Emissions of trace gases and aerosols from biomass burning, Global. Biogeochem. Cycles, 15, 955-966, 2001.

Butler, T. M, Simmonds, I., and Rayner, P. J.: Mass balance inverse modelling of methane in the 1990's using a Chemistry Transport Model, Atmos. Chem. Phys., 4, 2561-2580, 2004.

Bouwman, A. F., Lee, D. S., Asman, W. A. H., Dentener, F. J., van Der Hoek, K. W., and Olivier, J. G. J.: A global high-resolution emission inventory for ammonia, Global Biogeochem. Cycles, 11, 561-587, 1997.

Bouwman, A. F., Boumans, L. J. M., and Batjes, N. H.: Modeling global annual $\mathrm{N}_{2} \mathrm{O}$ and NO emissions from fertilized fields, Global Biogeochem. Cycles, 16(4), 1080, doi:10.1029/2001GB001812, 2002.

Dentener, F., Kinne, S., Bond, T., Boucher, O., Cofala, J., Generoso, S., Ginoux, P., Gong, S., Hoelzemann, J. J., Ito, A., Marelli, L., Penner, J. E., Putaud, J.-P., Textor, C., Schulz, M., van der Werf, G. R., and Wilson, J.: Emissions of primary aerosol and precursor gases in the years 2000 and 1750, prescribed data-sets for AeroCom, (data available from ftp://ftp.ei.jrc.it/pub/Aerocom/), Atmos. Chem. Phys. Discuss., 6, 2703-2763, 2006.

Dlugokencky, E. J., Steele, L. P., Lang, P. M., and Masarie, K. A.: The growth rate and distribution of atmospheric methane, J. Geophys. Res., 99, 17 021-17 043, 1994.

Eyring, V., Köhler, H. W., Van Aardenne, J., and Lauer, A.: Emissions from international 20 shipping, Part I: The last 50 years, J. Geophys. Res., J. Geophys. Res., 110, D17305, doi:10.1029/2004JD005619, 2006.

Galanter, M., Levy, H., and Carmichael, G. R.: Impacts of biomass burning on tropospheric $\mathrm{CO}, \mathrm{NO}_{x}$, and $\mathrm{O}_{3}$, J. Geophys. Res., 105, 6633-6653, 2000.

Gallagher, M. W., Nemitz, E., Dorsey, J. R., Fowler, D., Sutton, M. A., Flynn, M., and Duyzer, J.:

25 Measurements and parameterizations of small aerosol dry deposition velocities to grassland, arable crops, and forest: Influence of surface roughness length on deposition, J. Geophys. Res., 107, doi:10.1029/2001JD000817, 2002.

Ganzeveld, L. and Lelieveld, J.: Dry deposition parameterization in a chemistry general circulation model and its influence on the distribution of reactive trace gases, J. Geophys. Res., 100, 20 999-21 012, 1995.

Ganzeveld, L., Lelieveld, J., and Roelofs, G.-J.: Dry deposition parameterization of sulfur oxides in a chemistry and general circulation, J. Geophys. Res., 103, 5679-5694, 1998. 
Ganzeveld, L., Lelieveld, J., Dentener, F. J., Krol, M. C., Bouwman, A. F., and Roelofs, G.J.: The influence of soil-biogenic NOx emissions on the global distribution of reactive trace gases: the role of canopy processes, J. Geophys. Res., 107, doi:10.1029/2001JD001289, 2002.

5 Ganzeveld, L., Valverde-Canossa, J., Moortgat, G., and Steinbrecher, R.: Evaluation of Peroxide Exchanges over a Coniferous Forest in a Single-Column Chemistry-Climate Model, Atmos. Environ., in press, 2006.

Guenther, A., Nicolas Hewitt, C., Erickson, D., Fall, R., Geron, C., Graedel, T., Harley, P., Klinger, L., Lerdau, M., McKay, W. A., Pierce, T., Scholes, B., Steinbrecher, R., Tallamraju, R., Taylor, J., and Zimmerman, P.: A global model of natural volatile organic compound emissions, J. Geophys. Res., 100, 8873-8892, 1995.

Guenther, A., Karl, T., Harley, P., Wiedinmyer, C., Palmer, P. I., and Geron, C.: Estimates of global terrestrial isoprene emissions using MEGAN (Model of Emissions of Gases and Aerosols from Nature), Atmos. Chem. Phys. Discuss., 6, 107-173, 2006.

15 Graf, H. F., Feichter, J., and Langmann, B.: Volcanic degassing: Contribution to global sulphate burden and climate, J. Geophys. Res., 102, 10727-10738, 1997.

Hummelshøj, P., Jensen, N. O., and Larsen, S. E.: Particle dry deposition to a sea surface, in: Precipitation scavenging and atmosphere-surface exchange, 2, edited by: Schwartz, S. E. and Slinn, W. G. N., 829-840, Hemisphere Publishing Corporation, Washington, 1992.

20 Jöckel, P., Sander, R., Kerkweg, A., Tost, H., and Lelieveld, J.: Technical Note: The Modular Earth Submodel System (MESSy) - a new approach towards Earth System Modeling, Atmos. Chem. Phys., 5, 433-444, 2005.

Karl, T., Potosnak, M., Guenther, A., Clark, D., Walker, J., Herrick, J., and Geron, C.: Exchange processes of volatile organic compounds above a tropical rain forests: implications for modeling tropospheric chemistry above dense vegetation, J. Geophys. Res., 109, doi:10.1029/2004JD004738, 2004.

Kerkweg, A., Sander, R., Tost, H., and Jöckel, P.: Technical Note: Implementation of prescribed (OFFLEM), calculated (ONLEM), and pseudo-emissions (TNUDGE) of chemical species in the Modular Earth Submodel System (MESSy), Atmos. Chem. Phys. Discuss., 6, 5485$5504,2006 a$.

Kettle, A. J. and Andreae, M. O.: Flux of dimethylsulfide from the oceans: A comparison of updated data sets and flux models, J. Geophys. Res., 105, 26 793-26 808, 2000.

Liss, P. S. and Merlivat, L.: Air-sea exchange rates: Introduction and synthesis, in: The Role

$$
5477
$$

of Air-Sea Exchange in Geochemical cycling, edited by: Buat-Menard, P., pp. 113-127, D. Reidel, Norwell, Mass., 1984.

Monahan, E., Spiel, D., and Davidson, K.: Oceanic whitecaps and their role in air-sea exchange, chap. A model of marine aerosol generation via whitecaps and wave disruption, pp. 167-174, D., Reidel, Norwell, Massachusetts, 1986.

Nightingale, P. D., Malin, G., Law, C. S., Watson, A. J., Liss, P. S., Liddicoat, M., Boutin, J., and Upstill-Goddard, R. C.: In situ evaluation of sea-air exchange parameterization using novel conservative volatile tracers, Global Biogeochem. Cycles, 14, 373-378, 2000.

Olivier, J. G. H., van Aardenne, J. A., Dentener, F., Ganzeveld, L., and Peters, J. A. H. W.:

10 Recent trends in global greenhouse gas emissions: regional trends and spatial distribution of sources, Env. Sci., 2, 81-99, doi:10.1080/15693430500400345, 2005.

Roeckner, E., Bäuml, G., Bonaventura, L., Brokopf, R., Esch, M., Giorgetta, M., Hagemann, S., Kirchner, L., Kornblueh, L., Manzini, E., Rhodin, A., Schlese, U., Schulzweida, U., and Tompkins, A.: The atmospheric general circulation model ECHAM5. Part I: Model descrip-

15 tion, Report 349, Max Planck Institute for Meteorology, Hamburg, Germany, available from http://www.mpimet.mpg.de, 2003.

Sander, R., Kerkweg, A., Jöckel, P., and Lelieveld, J.: Technical Note: The new comprehensive atmospheric chemistry module MECCA, Atmos. Chem. Phys., 5, 445-450, 2005.

Sellers, P. J., Mintz, Y., Sud, Y. C., and Dalcher, A.: A simple biosphere model (SiB) for use within general circulation models, J. Atmos. Sci., 43, 505-531, 1986.

Slinn, W. G. N.: Predictions for particle deposition to vegetative canopies, Atmos. Environ., 16, 1785-1794, 1982.

Spiro, P. A., Jacob, D. J., and Logan, J. A.: Global Inventory of Sulfur Emissions With $1^{\circ} \times 1^{\circ}$ Resolution, J. Geophys. Res., 97, 6023-6036, 1992.

25 Stier, P., Feichter, J., Kinne, S., Kloster, S., Vignati, E., Wilson, J., Ganzeveld, L., Tegen, I., Werner, M., Balkanski, Y., Schultz, M., and Boucher, O.: The aerosol-climate model ECHAM5-HAM, Atmos. Chem. Phys., 5, 1125-1156, 2005.

Tost, H., Jöckel, P., Kerkweg, A., Sander, R., and Lelieveld, J.: Technical Note: A new comprehensive SCAVenging submodel for global atmospheric chemistry modelling, Atmos. Chem. Phys., 6, 565-574, 2006.

Van Aardenne, J. A., Dentener, F., Olivier, J. G. J., Peters, J. A. H. W., and Ganzeveld, L. N.: The EDGAR 3.2 Fast Track 2000 dataset (32FT2000), http://www.mnp.nl/edgar/model/ v32ft2000edgar/docv32ft2000/, 2005. 
Van der Werf, G. R., Randerson, J. T., Collatz, G. J., and Giglio, L.: Carbon emissions from fires in tropical and subtropical ecosystems, Global Change Biology, 9, 547-562, 2003.

Von Kuhlmann, R., Lawrence, M. G., and Crutzen, P. J.: A model for studies of tropospheric ozone and nonmethane hydrocarbons: Model descriptions and ozone results, J. Geophys. Res., 108, doi:10.1029/2002JD002893, 2003.

Von Kuhlmann, R., Lawrence, M. G., Pöschl, U., and Crutzen, P. J.: Sensitivities in global scale modeling of isoprene, Atmos. Chem. Phys., 4, 1-17, 2004.

Wanninkhof, R.: Relationship between wind speed and gas exchange over the ocean, J. Geophys. Res., 96, 2785-2796, 1992.

10 Wesely, M. L., Cook, D. R., and Hart, R. L.: Measurements and parameterization of particulate sulfur dry deposition over grass, J. Geophys. Res., 90, 2131-2143, 1985.

Wesely, M. L.: Parameterization of surface resistances to gaseous dry deposition in regionalscale numerical models, Atmos. Environ., 23, 1293-1304, 1989.

Wesely, M. L. and Hicks, B. B.: A review of the current status of knowledge on dry deposition, Atmos. Environ., 34, 2261-2282, 2000.

Yienger, J. J. and Levy II, H.: Global inventory of soil-biogenic NOx emissions, J. Geophys. Res., 100, 11447-11464, 1995.

Zhang, L., Gong, S., Padro, J., and Barrie, L.: A size-segregated particle dry deposition scheme for an atmospheric aerosol model, Atmos. Environ., 35, 549-560, 2001.

Table 1. Emission height profiles for the EDGARv3.2-FT2000 emission source categories, distinguishing 6 emission heights, 45, 140, 240400600 and $800 \mathrm{~m}$, where the numbers in the columns reflect the percentage of the total emission flux assigned to the specific height. The info source EMEP indicates profiles based on the EMEP model whereas AA indicates that these profiles are based on an arbitrarily assumption.

\begin{tabular}{|c|c|c|c|c|c|c|c|c|}
\hline Source category & Source name & $45 \mathrm{~m}$ & $140 \mathrm{~m}$ & $240 \mathrm{~m}$ & $400 \mathrm{~m}$ & $600 \mathrm{~m}$ & $800 \mathrm{~m}$ & Info source \\
\hline B10 & Industry & 0 & 4 & 19 & 41 & 30 & 6 & EMEP \\
\hline B20 & Power generation & 0 & 0 & 8 & 46 & 29 & 17 & EMEP \\
\hline B30 & Charcoal prod. & 100 & 0 & 0 & 0 & 0 & 0 & AA \\
\hline B40 & RCO & 50 & 50 & 0 & 0 & 0 & 0 & EMEP \\
\hline F10 & Industry & 0 & 4 & 19 & 41 & 30 & 6 & EMEP \\
\hline F20 & Power generation & 0 & 0 & 8 & 46 & 29 & 17 & EMEP \\
\hline F30 & OTS & 0 & 4 & 19 & 41 & 30 & 6 & EMEP \\
\hline F40 & RCO & 50 & 50 & 0 & 0 & 0 & 0 & EMEP \\
\hline F51 & Road transport & 100 & 0 & 0 & 0 & 0 & 0 & EMEP \\
\hline F54 & Non-Road transport & 100 & 0 & 0 & 0 & 0 & 0 & EMEP \\
\hline F58 & Inter. Shipping & 50 & 50 & 0 & 0 & 0 & 0 & AA \\
\hline F60 & Chem. Feedstock & 100 & 0 & 0 & 0 & 0 & 0 & AA \\
\hline F70 & Coal production & 90 & 10 & 0 & 0 & 0 & 0 & EMEP \\
\hline F80 & Oil production & 90 & 10 & 0 & 0 & 0 & 0 & EMEP \\
\hline F90 & Gas production & 90 & 10 & 0 & 0 & 0 & 0 & EMEP \\
\hline 110 & Iron and steel & 90 & 10 & 0 & 0 & 0 & 0 & EMEP \\
\hline 120 & Non-ferrous metals & 90 & 10 & 0 & 0 & 0 & 0 & EMEP \\
\hline 130 & Chemicals & 90 & 10 & 0 & 0 & 0 & 0 & EMEP \\
\hline 140 & Building materials & 90 & 10 & 0 & 0 & 0 & 0 & EMEP \\
\hline 150 & Pulp and paper & 90 & 10 & 0 & 0 & 0 & 0 & EMEP \\
\hline 160 & Food, bev, tobacco & 90 & 10 & 0 & 0 & 0 & 0 & EMEP \\
\hline 170 & Solvents & 100 & 0 & 0 & 0 & 0 & 0 & EMEP \\
\hline 190 & Misc. industry & 100 & 0 & 0 & 0 & 0 & 0 & EMEP \\
\hline L10 & Arable land & 100 & 0 & 0 & 0 & 0 & 0 & EMEP \\
\hline L15 & Rice cultivation & 100 & 0 & 0 & 0 & 0 & 0 & EMEP \\
\hline L20 & Animals & 100 & 0 & 0 & 0 & 0 & 0 & EMEP \\
\hline L30 & Animal waste man. & 100 & 0 & 0 & 0 & 0 & 0 & EMEP \\
\hline L41 & Deforestation & 0 & 100 & 0 & 0 & 0 & 0 & AA \\
\hline L42 & Savannah burning & 0 & 100 & 0 & 0 & 0 & 0 & AA \\
\hline L43 & Agric. waste burning & 0 & 100 & 0 & 0 & 0 & 0 & AA \\
\hline L44 & Vegetation fires & 0 & 100 & 0 & 0 & 0 & 0 & AA \\
\hline L45 & Deforestation indirect & 0 & 100 & 0 & 0 & 0 & 0 & AA \\
\hline L50 & Crop products & 100 & 0 & 0 & 0 & 0 & 0 & AA \\
\hline L70 & Indirect $\mathrm{N}_{2} \mathrm{O}$ & 100 & 0 & 0 & 0 & 0 & 0 & AA \\
\hline W10 & Landfills & 100 & 0 & 0 & 0 & 0 & 0 & AA \\
\hline W20 & Wastewater treatment & 10 & 15 & 40 & 35 & 0 & 0 & EMEP \\
\hline W30 & Human waste disposal & 10 & 15 & 40 & 35 & 0 & 0 & EMEP \\
\hline W40 & Waste incineration & 10 & 15 & 40 & 35 & 0 & 0 & EMEP \\
\hline W50 & Misc. waste handling & 10 & 15 & 40 & 35 & 0 & 0 & EMEP \\
\hline
\end{tabular}


Table 2. Global annual offline emissions per source category and total emission flux for the emission inventory and the one applied in $\mathrm{MATCH}$.

\begin{tabular}{lrrrrrr}
\hline $\begin{array}{l}\text { Chemical } \\
\text { Compound }\end{array}$ & Technological & Biofuel & Biomass burning & Biogenic & Total & $\mathrm{MATCH}^{1}$ \\
\hline $\mathrm{NO}_{\mathrm{x}}$ & & & & & & \\
$\mathrm{CO}$ & 31.4 & 2.5 & 9.3 & $0.0^{2}$ & 43.1 & $32.4^{3}$ \\
$\mathrm{SO}_{2}$ & 120.7 & 107.3 & 193.8 & 48.2 & 470.1 & 541 \\
$\mathrm{C}_{2} \mathrm{H}_{4}$ & 73.2 & 3.1 & 1.3 & & 76.0 & \\
$\mathrm{C}_{2} \mathrm{H}_{6}$ & 3.3 & 4.4 & 4.1 & 10.7 & 22.6 & 25.1 \\
$\mathrm{C}_{3} \mathrm{H}_{6}$ & 5.0 & 2.3 & 2.2 & 0.4 & 10.0 & 10.2 \\
$\mathrm{C}_{3} \mathrm{H}_{8}$ & 1.7 & 2.0 & 1.9 & 3.0 & 8.5 & 9.6 \\
$\mathrm{C}_{4} \mathrm{H}_{10}$ & 8.1 & 0.7 & 0.7 & 0.3 & 9.8 & 7.3 \\
$\mathrm{CH}_{3} \mathrm{CHO}$ & 59.9 & 0.1 & 0.9 & 0.3 & 62.1 & 40.4 \\
$\mathrm{CH}_{3} \mathrm{COCH}$ & 0.0 & 1.1 & 1.1 & 0.0 & 2.2 & 2.5 \\
$\mathrm{CH}_{3} \mathrm{COOH}$ & 1.9 & 1.2 & 1.1 & 25.6 & 29.8 & 28.6 \\
$\mathrm{CH}_{3} \mathrm{OH}$ & 0.0 & 2.6 & 2.5 & 1.4 & 6.5 & 7.2 \\
$\mathrm{HCHO}$ & 1.2 & 2.5 & 2.3 & 23.2 & 29.1 & 28.7 \\
$\mathrm{HCOOH}$ & 0.4 & 1.4 & 1.3 & 0.0 & 3.1 & 3.6 \\
$\mathrm{MEK}$ & 0.0 & 0.9 & 0.9 & 1.5 & 3.3 & 3.5 \\
$\mathrm{NH}_{3}$ & 2.8 & 2.9 & 2.8 & 0.0 & 8.5 & 8.4 \\
\hline
\end{tabular}

Units are in $\mathrm{Tg} \mathrm{C} / \mathrm{N} / \mathrm{S}$

${ }^{1}$ von Kuhlmann et al. (2003)

${ }^{2}$ Calculated online

${ }^{3}$ Total technological and biomass burning, excluding the soil-biogenic, aircraft and lightning contribution

5481

Table 3. Global annual online emissions calculated by EMDEP, applied in ECHAM5/MESSy, as function of three different model resolutions and the relative difference between the high and coarse resolution simulations resembling an 1-year integration from 1 February 1987 until 31 January 1988. The budgets are based on a 25-h out-put frequency of the instantaneous emissions.

\begin{tabular}{lrrrr}
\hline Compound & T42 & T21 & T63 & T63-T21 [\%] $^{1}$ \\
\hline $\mathrm{C}_{5} \mathrm{H}_{10}$ & 607.1 & 556.2 & 626.4 & 12.6 \\
$\mathrm{C}_{10} \mathrm{H}_{16}$ & 143.1 & 128.6 & 148.5 & 15.5 \\
ORVOC's & 254.6 & 227.2 & 266.2 & 17.2 \\
$\mathrm{NO}_{\mathrm{x}}$, soil & 12.4 & 12.7 & 12.3 & -3.1 \\
$\mathrm{NO}_{\mathrm{x}}$, canopy & 8.4 & 8.6 & 8.3 & -3.5 \\
DMS & 17.3 & 16.3 & 17.6 & 8.0 \\
Dust & $1432^{2}$ & - & - & - \\
Seasalt & $5906(64,5842)^{3}$ & $5199(56,5143)$ & $6258(68,6190)$ & \\
\hline
\end{tabular}

Units are in $\mathrm{Tg} \mathrm{C} / \mathrm{N} / \mathrm{S} /$ dust/sea salt

${ }^{1}$ Relative difference relative to T21 budget

${ }^{2}$ The dust emissions appear to be highly resolution dependent and are only presented for the T42 resolution, the resolution for which the emission scheme has been developed

${ }^{3}$ The numbers in parentheses reflect accumulation- and coarse mode emissions, respectively 

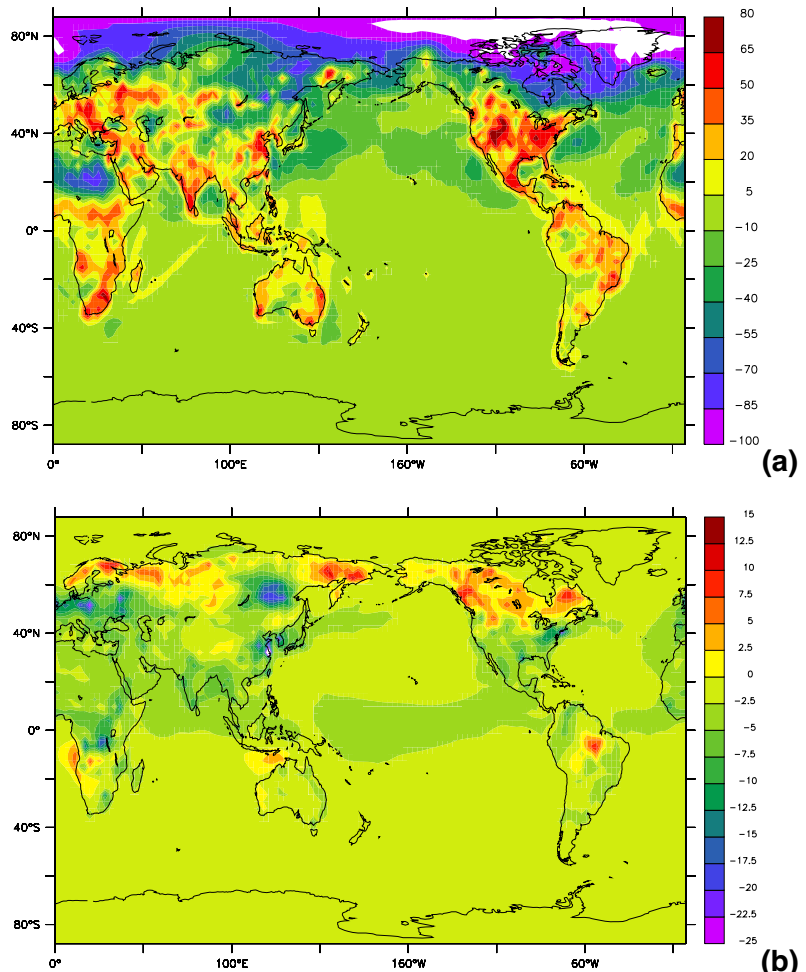

(b)

Fig. 1. Relative change in annual mean $\mathrm{SO}_{2}\left(\right.$ a) and $\mathrm{O}_{3}$ (b) dry deposition fluxes due to emitting all $\mathrm{SO}_{2}$ and $\mathrm{O}_{3}$ precursors in the surface layer instead of including the recommended emission heights for technological and biomass burning emissions according to EDGARv3.2-FT2000. The white areas in the Artic in (a) denote relative differences $\leq 100 \%$. 